\title{
Prostaglandin production by ovine embryos and endometrium in vitro
}

\author{
J. H. Hyland*, J. G. Manns and W. D. Humphrey† \\ Department of Veterinary Physiological Sciences, W.C.V.M., University of Saskatchewan, \\ Saskatoon, Saskatchewan, Canada, S7N OWO
}

\begin{abstract}
Summary. For Day-14 sheep embryos, mean ( \pm s.e.m., $n=7$ ) PGE release was $20.2 \pm 5.0,13.0 \pm 1.9$ and $6.7 \pm 1.9 \mathrm{ng} \cdot \mathrm{mg}$ tissue ${ }^{-1} \cdot \mathrm{h}^{-1}$ after $0.5,4.5$ and $8.5 \mathrm{~h}$ of culture respectively, while mean PGF release rates ( \pm s.e.m.) for the same periods were $98.5 \pm 24.4,49.3 \pm 16.3$ and $16.5 \pm 5.4 \mathrm{ng} . \mathrm{mg}$ tissue $\mathrm{e}^{-1} \cdot \mathrm{h}^{-1}$, respectively. Total quantities of PGE and PGF released after $8.5 \mathrm{~h}$ of culture were $707 \mathrm{ng}$ and $1833 \mathrm{ng}$ per embryo, respectively. Embryos $(n=21)$ collected between Days 13 and 15 of gestation contained $25.4 \pm 6.9 \mathrm{ng}$ PGE and $66.2 \pm 23.2 \mathrm{ng}$ PGF/ embryo. A total PG release 28 times the embryonic content of PG suggested active PG production by the embryos. Co-culture of embryos with endometrium resulted in $P G$ release rates which were not significantly higher than those from embryos cultured alone. Release of PGE and PGF from embryos declined with time, that for PGF being significantly $(P<0.05)$ reduced after $8.5 \mathrm{~h}$ incubation. Co-culture of embryos and endometrium had no effect on rate of decline of PG production over time. Day 14 endometrium from pregnant or non-pregnant ewes produced very small quantities of both PGs by comparison with embryos, and there was no consistent trend for $P G$ production rate over time.
\end{abstract}

\section{Introduction}

Regression of the corpus luteum (CL) in the cyclic ewe occurs 14-15 days after onset of oestrus (Deane, Hay, Moor, Rowson \& Short, 1966), due to release of a uterine luteolysin, which is generally accepted to be prostaglandin (PG) F-2 $\alpha$ (Goding, 1974). The presence of an embryo in the uterus 12-13 days after oestrus results in maintenance of the CL (Moor \& Rowson, 1966). The nature of the embryonic signal and how it functions is not known, but PGE-2 has been suggested as a potential anti-luteolysin in the ewe (Ellinwood, Nett \& Niswender, 1979). Prostaglandin E-2 counteracted PGF-2 $\alpha$-induced luteolysis when the two were infused simultaneously into ovarian autotransplants (Henderson, Scaramuzzi \& Baird, 1977) and, when infused into the uterus of cyclic or oestrogen-treated ewes, PGE-2 prolonged CL lifespan (Magness, Huie \& Weems, 1978; Colcord, Hoyer \& Weems, 1978; Reynolds et al., 1980). Furthermore, endometrium from Day-15 pregnant ewes secreted significantly higher quantities of PGE-2 in culture than did endometrium from non-pregnant ewes at the equivalent stage of the cycle (Ellinwood et al., 1979). In another study (Marcus \& Hackett, 1979), endometrial cells, harvested from ewes between Days 12 and 15 of pregnancy, converted radioactive arachidonic acid to PGE-2, whereas cells collected from non-pregnant ewes did not show this activity.

* Present address: Department of Veterinary Preclinical Sciences, University of Melbourne, Parkville, Victoria 3052, Australia.

† Present address: Department of Animal Science, Mississippi State University, Mississippi 39762, U.S.A. 
In addition, PGE-2 and PGF-2 $\alpha$ were produced during culture of cow (Shemesh, Milaguir, Ayalon \& Hansel, 1979) and rabbit (Dey, Chien, Cox \& Crist, 1980) embryos. Therefore, there are a number of studies which implicate PGE-2 in luteal maintenance during early pregnancy in the ewe, but no study on PG production by ovine embryos has been published.

The aims of this experiment were to determine whether preimplantation ovine embryos were capable of PG production in vitro, and whether production was altered when embryos were cocultured with endometrium from pregnant or non-pregnant ewes 14 days after oestrus. Prostaglandin production by endometrial tissue from pregnant and non-pregnant ewes was also studied.

\section{Materials and Methods}

\section{Collection of embryos for $P G$ analysis}

Embryos were collected between Days 13 and 15 of pregnancy from 37 ewes of the Finnish Landrace type. The ewes were examined for oestrus twice daily, using a vasectomized ram, and all animals had two normal oestrous cycles (16-18 days) before the experiment. On Day 10 of an oestrous cycle (day of oestrus = Day 0 ) the ewes were induced to superovulate with an injection of 1000 i.u. PMSG (Ayerst Laboratories, Montreal, Canada), followed on Day 12 by 15 mg PGF-2 $\alpha$ (Prostin: Upjohn Company, Kalamazoo, Michigan, U.S.A.). When the ewes displayed oestrus they were mated to an intact ram.

On Days 13-15 of pregnancy general anaesthesia was induced with sodium thiamylal and maintained with halothane in oxygen. A midventral laparotomy was performed and the embryos flushed from the uterus with sterile $0.15 \mathrm{M}$-saline at $37^{\circ} \mathrm{C}$. Embryos were removed immediately from the flushings, washed in cold $\left(4^{\circ} \mathrm{C}\right)$ saline, placed in snap-cap vials and frozen at $-60^{\circ} \mathrm{C}$ until assayed for prostaglandins.

In preparation for PG analysis, the embryos were thawed, homogenized in ice-cold saline and freeze dried. The samples were reconstituted to $1-5 \mathrm{mg}$ dried wt per $\mathrm{ml}$ in $0.05 \mathrm{M}$-phosphate buffer containing $3 \mathrm{mM}$-EDTA, $0.15 \mathrm{M}$-sodium chloride and $0.1 \mathrm{~mm}$-thiomersal (PBS) (all from the Sigma Chemical Co., St Louis, Missouri, U.S.A.).

\section{Collection of embryos and endometrium for incubation}

Two ewes were induced to superovulate as described above and mated to an intact ram at oestrus. An untreated ewe, showing oestrus at the same time, was mated by a vasectomized ram. On Day 14 after mating, the 3 ewes underwent laparotomies and 28 embryos were recovered. Endometrium was stripped off the uterus of the non-pregnant ewe and that of one of the pregnant ewes. The endometrial samples were chopped with fine scissors, washed with culture medium and placed in separate beakers of culture medium at $37^{\circ} \mathrm{C}$ until added to incubation flasks. Embryos from each ewe were pooled and also held in culture medium before incubation.

\section{Incubation procedure}

Culture medium used was Dulbecco's phosphate-buffered saline (Gibco, Grand Island, New York), which contained $0.33 \mathrm{~mm}$-sodium pyruvate, $5.56 \mathrm{~mm}$-glucose (Sigma), 100 i.u. penicillin $\mathrm{G}$ (Crystapen: Glaxo Laboratories)/ml, $50 \mu \mathrm{g}$ streptomycin sulphate (Pfizer Co. Ltd, Montreal)/ml and 10\% normal sheep serum (Moore \& Spry, 1972). The pH of the culture medium was $7 \cdot 2$.

Incubations were carried out in Erlenmeyer flasks $(25 \mathrm{ml})$ on Dubnoff shaking incubators at $37^{\circ} \mathrm{C}$, with air as the gas phase. Embryos and/or endometrium were added to flasks in a 
systematic manner which removed possible effects of time on tissue viability across treatments. The five incubation treatments were embryo (I), embryo plus endometrium from pregnant ewe (II), embryo plus endometrium from non-pregnant ewe (III), endometrium from pregnant ewe (IV) and endometrium from non-pregnant ewe (V). Each flask contained one embryo and/or $\simeq 100 \mathrm{mg}$ wet wt endometrium, which was weighed on a torsion balance before addition to flasks. There were 7 flasks per treatment replicate.

An initial $0.5 \mathrm{~h}$ incubation in $10 \mathrm{ml}$ culture medium was followed by incubation for a further $8 \mathrm{~h}$ in an initial volume of $15 \mathrm{ml}$ fresh culture medium. An aliquot of medium $(5 \mathrm{ml})$ was aspirated from the flasks after $4.5 \mathrm{~h}$, added to vials on solid $\mathrm{CO}_{2}$ and subsequently stored at $-60^{\circ} \mathrm{C}$ until assayed for prostaglandins. At the end of incubation for $8.5 \mathrm{~h}$ the remaining medium $(10 \mathrm{ml})$ was decanted from the flasks and similarly treated. Embryos were then removed, blotted dry and weighed on an analytical balance.

\section{Prostaglandin radioimmunoassay}

Antisera were raised in sheep to PGE-2 or PGF-2 $\alpha$ conjugated to bovine serum albumin (Caldwell, Burstein, Brock \& Speroff, 1971). Cross-reactions of the antisera were tested against PGA-1, PGB-1, PGE-1, PGE-2, PGF-1 $\alpha$, PGF-2 $\alpha, 15$-keto PGE-2, 15-keto PGF-2 $\alpha, 13,14-$ dihydro-15-keto PGE-2 (PGEM), PGFM and arachidonic acid. Significant cross-reactants to the PGE- 2 antiserum were PGE-1 (100\%) and PGF- $\alpha$ (2.5\%), while PGF-1 $\alpha(100 \%)$ was the only prostaglandin tested to cross-react significantly with the PGF- $2 \alpha$ antiserum. Because of the cross-reaction data, prostaglandins assayed using these antisera are referred to as PGE and PGF. The PGE and PGF antisera were used in the assay at an initial dilution of 1/50 and $1 / 1000$ respectively.

Radioactive prostaglandins, $\left[5,6,7,8,9,10,11,12,14,15-{ }^{3} \mathrm{H}\right] \mathrm{PGE}-2$ (sp. act. $130 \mathrm{Ci} / \mathrm{mmol}$ ) and $\left[5,6,7,8,9,10,11,12,14,15-{ }^{3} \mathrm{H}\right] \mathrm{PGF}-2 \alpha$ (sp. act. $120 \mathrm{Ci} / \mathrm{mmol}$ ), were purchased from New England Nuclear, Boston, Massachusetts, U.S.A. The buffer used in the assay was PBS plus $0 \cdot 1 \%(\mathrm{w} / \mathrm{v})$ gelatin.

Aliquots $(0.125 \mathrm{ml})$ of embryo homogenate and culture medium were acidified to $\mathrm{pH} 3.5-$ 4.0 using $0.1 \mathrm{~N}-\mathrm{HCl}$, and extracted with $5 \mathrm{ml}$ ethyl acetate (Douglas \& Ginther, 1976). The ethyl acetate phase was dried under a stream of nitrogen and applied to columns of acidwashed Florisil (Carroll, 1963) for chromatographic separation of PGE and PGF, as modified from Banschbach \& Love (1979). PGE was eluted with $8 \mathrm{ml}$ of a benzene:ethyl acetate: methanol solution $(60: 40: 2.5$ by vol.; Solvent I) and PGF with $4 \mathrm{ml}$ of a solution of benzene: ethyl acetate :methanol $(60: 40: 20$ by vol., Solvent II). The last $3 \mathrm{ml}$ of Solvent I were discarded because of contamination with PGF, and $0.5 \mathrm{ml}$ Solvent I and $0.4 \mathrm{ml}$ Solvent II were removed for recovery calculations. The remaining solvent was divided into three equal volumes, added to assay tubes and dried under nitrogen. To reduce solvent blank values, $1.5 \mathrm{ml}$ Solvent I and $1.2 \mathrm{ml}$ Solvent II were added to standard tubes for PGE and PGF respectively, and dried under nitrogen.

Antiserum $(100 \mu \mathrm{l})$ and the labelled PG $(100 \mu \mathrm{l} ; 37 \mathrm{pg} /$ tube $)$ were added to appropriate sample and standard tubes and incubated overnight on a shaker at $4^{\circ} \mathrm{C}$. Free and bound hormone were separated by addition of $1 \mathrm{ml} 0.25 \%$ activated charcoal (Norit A, J. T. Baker Chemical Co., New Jersey, U.S.A.) in assay buffer. The samples were allowed to stand for 10 min at $4^{\circ} \mathrm{C}$, centrifuged for $10 \mathrm{~min}$ at $2000 \mathrm{~g}$ and the supernatants decanted into scintillation vials for counting.

Radioactive tracer $(\sim 3.7 \mathrm{pg})$ was added to the samples before extraction. Average recovery (mean \pm s.e.m.) after extraction and chromatography of embryo homogenates was $41 \pm 4 \%$ $(n=10)$ and $69 \pm 6 \%(n=11)$ for PGE-2 and PGF-2 $\alpha$ respectively. Recoveries from culture medium were $68 \pm 2 \%(n=58)$ and $76 \pm 2 \%(n=54)$ for PGE-2 and PGF- $2 \alpha$ respectively. 
Results were calculated by hand and corrections were made for recovery, sample volumes and endogenous PGs in sheep serum added to culture medium. Samples of PBS and culture medium containing known amounts $(0 \cdot 2-40 \mathrm{ng} / \mathrm{ml})$ of PGE-2 and PGF- $2 \alpha$ were included in each assay. Regression analysis of PGE-2 added to PBS and that measured gave a correlation coefficient $(r)$ of 0.99 with a slope of $0.97(n=26)$. Similar calculations for PGF- $2 \alpha$ gave $r=0.99$ and a slope of $1.02(n=21)$. The PGE-2 and PGF-2 $\alpha$ added to culture medium could be quantitatively recovered. Correlation between PGE-2 added and PGE measured was $r=0.99$, with a slope of $1.02(n=24)$, while values for PGF-2 $\alpha$ were $r=0.99$ with a slope of $1.03(n=18)$. Assay sensitivity, measured as the mean blank value $(1.4$ and $2.8 \mathrm{pg} /$ tube in the PGE and PGF assays, respectively) plus two standard deviations from the mean (Abrahams, Odell, Edwards \& Purdy, 1970), was $70 \mathrm{pg} \mathrm{PGE} / \mathrm{ml}(n=8)$ and $138 \mathrm{pg}$ PGF/ml $(n=8)$. Intraassay coefficients of variation for PGE and PGF based on $0.2-40 \mathrm{ng} / \mathrm{ml}$ samples, were $7.3 \%$ $(n=10)$ and $12.5 \%(n=9)$ respectively, while inter-assay coefficients of variation were $9.4 \%$ $(n=20)$ and $17.9 \%(n=21)$, respectively.

\section{Statistical analysis}

Because variances were heterogeneous, the Kruskal-Wallis test (Gibbons, 1971) was used except when rate of decline of prostaglandin production was analysed. In this case, the data were subjected to $\log$ transformation and a $3 \times 3$ factorial analysis of variance, comparing time by treatment interactions between Treatments I, II and III and the three incubation periods.

\section{Results}

A total of 21 pooled embryo samples was analysed. The mean ( \pm s.e.m.) PGE and PGF content was $25.4 \pm 6.9$ and $66 \cdot 2 \pm 23.2 \mathrm{ng}$. embryo ${ }^{-1}$, respectively.

Average weight ( \pm s.e.m.) of embryos after $8.5 \mathrm{~h}$ in culture was $5.1 \pm 0.8 \mathrm{mg}(n=19)$. Weights of two embryos from Treatments II and III were missing when results were calculated and have been omitted from the data. Consequently, $n=7$ for Treatments I, IV and V, and $n=6$ for Treatments II and III.

\section{$P G E$}

Endometrial PGE release into culture medium ranged between 0.01 and $0.1 \mathrm{ng} . \mathrm{mg}$ tissue $\mathrm{e}^{-1}$. $\mathrm{h}^{-1}$ and showed no consistent pattern over time of incubation. It is not statistically possible to compare PG release rates from endometrium from pregnant and non-pregnant ewes because tissue was collected from only one animal in each group.

There was a high PGE release rate into culture medium by embryos (Table 1, Treatment I), which was some 200 times higher than that of endometrium cultured alone (Treatments IV and V) on a weight basis. The co-culture of endometrium and embryos (Treatments II and III) did not cause a significant increase of PGE release rate into medium.

PGE release rate declined with increasing incubation time in treatments which contained embryos, but there was no significant difference in PGE release rate at any stage of incubation, within these treatment groups. There was no treatment by time interaction in the analysis of variance which indicated that PGE release over time was not affected by co-culture of embryos and endometrium. 
Table 1. Mean ( \pm s.e.m.) release rate (ng.mg embryo ${ }^{-1} \cdot \mathrm{h}^{-1}$ ) of PGE and PGF by cultured ovine embryos and endometrium collected on Day 14 after oestrus

\begin{tabular}{|c|c|c|c|}
\hline \multirow[b]{2}{*}{$\begin{array}{l}\text { Duration of } \\
\text { incubation } \\
\text { (h) }\end{array}$} & \multicolumn{3}{|c|}{ Treatments } \\
\hline & $\begin{array}{c}1 \\
\text { (embryos) }\end{array}$ & $\begin{array}{l}\text { II } \\
\text { (embryos + pregnant } \\
\text { endometrium) }\end{array}$ & $\begin{array}{c}\text { III } \\
\text { (embryos + non-pregnant } \\
\text { endometrium) }\end{array}$ \\
\hline $\begin{array}{l}\text { No. of embryos } \\
\text { PGE } 0.5 \\
4.5 \\
8.5\end{array}$ & $\begin{array}{c}7 \\
20 \cdot 2 \pm 5 \cdot 0 \\
13 \cdot 0 \pm 1 \cdot 9 \\
6 \cdot 7 \pm 1 \cdot 9\end{array}$ & $\begin{array}{c}6 \\
27 \cdot 6 \pm 9 \cdot 1 \\
16 \cdot 1 \pm 4 \cdot 5 \\
8 \cdot 3 \pm 2 \cdot 0\end{array}$ & $\begin{array}{c}6 \\
33.8 \pm 15.9 \\
25.5 \pm 10.4 \\
20.5 \pm 8.9\end{array}$ \\
\hline $\begin{array}{r}\text { PGF } 0.5 \\
4 \cdot 5 \\
8 \cdot 5\end{array}$ & $\begin{array}{l}98 \cdot 5 \pm 24 \cdot 4^{\mathrm{a}} \\
49 \cdot 3 \pm 16 \cdot 3^{\mathrm{b}} \\
16 \cdot 5 \pm 5 \cdot 4^{\mathrm{b}}\end{array}$ & $\begin{aligned} 117 \cdot 6 & \pm 21 \cdot 1^{\mathrm{a}} \\
58 \cdot 5 & \pm 10 \cdot 7^{\mathrm{ab}} \\
30 \cdot 3 & \pm 7 \cdot 7^{\mathrm{b}}\end{aligned}$ & $\begin{array}{l}110 \cdot 3 \pm 21 \cdot 8^{\mathrm{a}} \\
78 \cdot 1 \pm 15 \cdot 2^{\mathrm{a}} \\
21 \cdot 5 \pm 7 \cdot 7^{\mathrm{b}}\end{array}$ \\
\hline
\end{tabular}

Means with different superscripts within columns are significantly different $(P<0.05)$.

\section{$P G F$}

PGF release rates were consistently higher than those of PGE at all stages of incubation (Table 1). PGF output by embryos (Treatment I) on a weight basis was up to 1000 times higher than that from endometrium cultured alone (Treatments IV and V), which ranged between 0.03 and $0.2 \mathrm{ng} \cdot \mathrm{mg}$ tissue $\mathrm{e}^{-1} \cdot \mathrm{h}^{-1}$. Co-culture of embryos and endometrium did not cause a significant increase of $\mathrm{PGF}$ release.

PGF release declined as the incubation proceeded, the release rate after $8.5 \mathrm{~h}$ of culture being significantly $(P<0.05)$ lower than at $0.5 \mathrm{~h}$. Analysis of variance showed that there was no treatment by time interaction in Treatments I, II and III, which indicated that co-culture of embryos and endometrium had no effect on rate of decline of PGF release.

\section{Discussion}

Substantial quantities of both PGE end PGF were released into culture medium by embryos. Freeze dried embryos, analysed concurrently with culture medium, contained $25.5 \mathrm{ng} P \mathrm{PGE}$ and 66.2 ng PGF per embryo. Total PGE and PGF released by embryos (Treatment I) during incubation was $707 \mathrm{ng}$ and $1833 \mathrm{ng}$, respectively, and therefore approximately 28 times more PGs were released into the culture medium than were contained in similar embryos, and strongly suggest active PG synthesis by embryos. Bovine embryos, collected between Days 13 and 16 of gestation, are reported to contain PGE-2 and PGF, and to produce these PGs in culture (Shemesh et al., 1979), and can convert radioactive arachidonic acid to PGE-2 in vitro (Thatcher et al., 1980). The magnitude of PG production by the embryos in this experiment was surprising and may partly explain the high levels found in uterine flusings by Ellinwood et al. (1979) on Days 15 and 17 of gestation.

By comparison to that of embryos, PG release rate by endometrium from pregnant and non-pregnant animals was negligible. However, total weight of endometrium per uterus is approximately $10 \mathrm{~g}$ (Huslig, Fogwell \& Smith, 1979), and calculation of endometrial PG production per uterus $\left(\times 10^{4}\right)$ gives amounts considerably higher than those produced by embryos. The endometrial PGE and PGF release rates recorded here are similar to those recorded under similar culture conditions by Ellinwood et al. (1979).

The production of higher amounts of PGF than PGE by embryos at a time when luteal maintenance is crucial to pregnancy is difficult to rationalize. However, similar findings have been recorded by other workers; Wilson, Butcher \& Inskeep (1972) observed that concentra- 
tions of PGF-2 $\alpha$ in uterine venous plasma and endometrium were greater in pregnant than in non-pregnant ewes on Day 13 after oestrus, and Ellinwood et al. (1979) showed that PGF-2 $\alpha$ concentrations in endometrium and uterine flushings were higher in pregnant ewes than in non-pregnant ewes on Day 15. If PGE-2 is an antiluteolysin, its production by the embryos may be accompanied by a non-specific increase in PGF secretion. If this is so, PGE-2 could perhaps counteract the luteolytic effects of PGF-2 $\alpha$ (Henderson et al., 1977) at this time.

We thank Dr J. Lauderdale and Dr J. Pike, the Upjohn Company, Kalamazoo, Michigan, for the pure prostaglandins; Mrs Brenda Todd for diligent technical expertise; and Dr R. Jarrett and Ms V. Lord, CSIRO Division of Mathematics and Statistics, for assistance with the statistical analysis. The work was supported by a grant from the Department of Supply and Services, Government of Canada.

\section{References}

Abrahams, G.E., Odell, W.D., Edwards, R. \& Purdy, J.M. (1970) Solid-phase radioimmunoassay of estrogens in biological fluids. Acta endocr., Copenh. Suppl. 147, 332-346.

Banschbach, M.W. \& Love, P.K. (1979) Use of minicolums packed with acid-washed Florisil for the rapid separation of $\mathrm{A}, \mathrm{E}$, and $\mathrm{F}$ series prostaglandins. Prostaglandins 17, 193-200.

Caldwell, B.V., Burstein, S., Brock, W.A. \& Speroff, L. (1971) Radioimmunoassay of the F prostaglandins. J. clin. Endocr. Metab. 33, 17!-178.

Carroll, K.K. (1963) Acid-treated Florisil as an adsorbent for column chromatography. J. Am. Oil. Chem. Soc. 40, 413-419.

Colcord, M.L., Hoyer, G.L. \& Weems, C.W. (1978) Effect of prostaglandin E-2 as an antiluteolysin in estrogen-induced luteolysis in ewes. J. Anim. Sci. 46, Suppl. 1, 352, Abstr.

Deane, H.W., Hay, M.F., Moor, R.M., Rowson, L.E.A. \& Short, R.V. (1966) The corpus luteum of the sheep: relationships between morphology and function during the oestrus cycle. Acta endocr., Copenh. 51, 245-263.

Dey, S.K., Chien, S.M., Cox, C.L. \& Crist, R.D. (1980) Prostaglandin synthesis in the rabbit blastocyst. Prostaglandins 19,449-453.

Douglas, R.H. \& Ginther, O.J. (1976) Concentrations of prostaglandins $F$ in uterine venous plasma of anesthetized mares during the estrous cycle and early pregnancy. Prostaglandins 11, 251-260.

Ellinwood, W.E., Nett, T.M. \& Niswender, G.D. (1979) Maintenance of the corpus luteum of early pregnancy in the ewe. II. Prostaglandin secretion by the endometrium in vitro and in vivo. Biol. Reprod. 21, 845-856.

Gibbons, J. (1971) Non-Parametric Statistical Inference. McGraw-Hill, New York.

Goding, J.R. (1974) The demonstration that PGF-2 $\alpha$ is the luteolysin in the ewe. J. Reprod. Fert. 38 , $261-271$.
Henderson, K.M., Scaramuzzi, R.J. \& Baird, D.T. (1977) Simultaneous infusion of prostaglandin E-2 antagonizes the luteolytic action of prostaglandin F-2 $\alpha$ in vivo. $J$. Endocr. 72, 379-383.

Huslig, R.L., Fogwell, R.L. \& Smith, W.L. (1979) The prostaglandin forming cyclooxygenase of ovine uterus: relationship to luteal function. Biol. Reprod. 21, 589-600.

Magness, R.R., Huie, J.M. \& Weems, C.W. (1978) Effect of contralateral and ipsilateral intrauterine infusion of prostaglandin E-2. J. Anim. Sci. 46, Suppl. 1, Abstr. 376.

Marcus, G.J. \& Hackett, E.T. (1979) Endometrial synthesis of prostaglandin $\mathrm{E}_{2}$ : an indication of early maternal recognition of pregnancy? J. Anim. Sci. 49, Suppl. 1, Abstr. 432.

Moor, R.M. \& Rowson, L.E.A. (1966) The corpus luteum of the sheep: effect of the removal of embryos on luteal function. J. Endocr. 34, 497-502.

Moore, N.W. \& Spry, G.A. (1972) The culture of fertilized sheep ova. J. Reprod. Fert. 28, 139, Abstr.

Reynolds, L., Huie, J., Stalcup, B., Magness, R., Hoyer, G., Weems. C. \& Behrman, H. (1980) Effect of $\mathrm{PGE}_{1}$ or $\mathrm{PGE}_{2}$ on $\mathrm{CL}$ in ewes. J. Anim. Sci. 51, Abstr. 519.

Shemesh, M., Milaguir, F., Ayalon, N. \& Hansel, W. (1979) Steroidogenesis and prostaglandin synthesis by cultured bovine blastocysts. J. Reprod. Fert. 56, $181-185$.

Thatcher, W.W., Lewis, G.S., Eley, R.M., Bazer, F.W., Fields, M.J., Williams, W.F. \& Wilcox, C.J. (1980) Contribution of the bovine conceptus to the endocrinological phenomenon existing at implantation, during gestation and around parturition. Proc. 9th Int. Cong. Anim. Reprod. \& A.I., Madrid, pp. 9-22.

Wilson, L., Butcher, R.L. \& Inskeep, E.K. (1972) Prostaglandin F- $2 \alpha$ in the uterus of ewes during early pregnancy. Prostaglandins 1, 479-482. 